\title{
Maggot Debridement Therapy in the Treatment of Footrot and Foot Scald in Sheep
}

\author{
A. KOČIŠOVÁ, J. PISTL ${ }^{1}$, R. LINK², E. ČONKOVÁ ${ }^{3}$, M. GOLDOVÁ \\ Department of Parasitology, Diseases of Fish, Bees and Game, \\ ${ }^{1}$ Department of Microbiology and Immunology, \\ ${ }^{2}$ II. nd Internal Clinic, ${ }^{3}$ Department of Pharmacology, University of Veterinary Medicine, \\ Košice, Slovak Republic
}

Received May 6, 2005

Accepted March 16, 2006

\begin{abstract}
Kočišová A., J. Pistl, R. Link, E. Čonková, M. Goldová: Maggot Debridement Therapy in the Treatment of Footrot and Foot Scald in Sheep. Acta Vet. Brno 2006, 75: 277-281.

In sheep with acute and chronic interdigital skin inflammation, maggot therapy was used for the debridement and speeding up the healing process. Sheep were housed at the university farm Zemplínska Teplica and before using maggot therapy, they were unsuccessfully treated by a footbath containing 10\% copper sulphate and topical application of oxytetracycline solution in alcohol. Six non-pregnant Valachian sheep between two to four years of age, weighing 43 to $57 \mathrm{~kg}$ were treated with maggots of Lucilia sericata (Meigen) (Diptera: Calliphoridae). The larval population should be 8-12 per square centimetre of wound, but all affected tissues were trimmed away before their application. The effect of a single application for 3-6 days was evaluated. Debridement was rapid and selective. The treatment was well tolerated by animals. New layers of healthy tissue were formed over the wounds. It was observed that maggots of $L$. sericata are capable of cleaning the wounds after single application.
\end{abstract}

Fly larvae; Lucilia sericata; clinical cure; dermatitis interdigitalis acuta; pododermatitis purulenta

Ovine foot rot is a highly contagious disease affecting the interdigital tissue of sheep. It is one of the most common causes of severe lameness and can result in serious economic loss from decreased meat and flock production. Foot rot is caused by an interaction of two anaerobic bacteria, Dichelobacter nodosus (previously Bacteroides nodosus) and Fusobacterium necrophorum (previously Sphaerophorus necrophorus) (Whittier and Umberger 1997). Foot scald (interdigital dermatitis) is an infection of only $F$. necrophorum and is not contagious. Footrot and foot scald tend to be seasonal, with the highest incidence occurring during the wet seasons. Cuts, bruises, puncture wounds, or severe abrasions of the foot due to sharp rocks and sticks will damage the skin in the interdigital space and predispose sheep to footrot by allowing bacteria to invade and multiply within the tissue. Lameness is usually the first sign of an infected animal and is typically followed by reddening of the interdigital tissue and swelling of the foot, causing spreading of the toes. If footrot and foot scald are not controlled, they may invade deeper structures of the foot, including joints which may lead to the septic arthritis. Foot bathing in $10 \%$ zinc sulphate or copper sulfate are recommended but for severe cases antibiotic therapy is necessary (Boundry 1983; Griffin 1998). But on the other hand when the resistance to antibiotics is developed, the healing is delayed. Maggot therapy has been successfully used as a new alternative method to treat the wounds with necrosis of the soft tissues, especially of cutis and subcutis.

Information about successful healing of wounds with the help of fly larvae dates back to the ancient times. The beneficial effect of fly larvae on difficult-to-heal wounds was first observed and described in 1557 by Ambrois Paré, the chief surgeon of Charles IX and Henry VIII. The beginnings of scientifically based healing of refractory wounds in human medicine

Address for correspondence:

Alica Kočišová

Department of Parasitology, Diseases of Fish, Bees and Game

University of Veterinary Medicine

Komenského 73,041 81 Košice

Slovak Republic

Phone: +421556332213

Fax: +421556323666

e-mail: kocisova@uvm.sk

http://www.vfu.cz/acta-vet/actavet.htm 
with the help of fly larvae stretch back to the World War I and are attributed to Dr. W.S. Baer. Back in the 1920s and 1930s he successfully treated more than 90 patients suffering from osteomyelitis and chronic ulcerosis. In the mid 1940s this treatment was gradually replaced by antibiotics and new surgical treatment procedures. However, the increase in numbers of micro-organisms resistant to antibiotics forced the professionals to return to the larval therapy (Dis s emond et al. 2002). New intensive clinical studies, which are still in progress, have been initiated by Dr. Ronald Sherman at the University of California. He proved that larval therapy is very effective particularly if it is applied to excise infected and gangrenous wounds and bedsores. This method can be used to treat the trophic ulcer (ulcus cruris), the crural skin defect which develops mostly on the basis of chronic venous insufficiency, post-traumatic, diabetic and ischaemic ulcers, traumatic, inflammatory and neurotic bedsores. Successful treatment of osteomyelitis has also been described (S herman and Pechter 1988). The conditions described are usually treated surgically with the help of antibiotics, or even analgetics in the more serious cases. However, the problem may persist and thus new field opens up for the non-traditional treatment with fly larvae. The experience with the use of larvae in human medicine is more abundant than that in veterinary medicine (Hin shaw 2000). In veterinary medicine we know of only two studies in which successful larval therapy was applied to treat actinomycosis in cattle (Dicke 1953), and experimental burns in rats (Vistne s et al. 1981). In Slovakia, larval therapy has been used successfully at the University of Veterinary Medicine in Košice since the year 2000. The first animals treated in this way were breeding rabbits with joint abscesses that resisted to conventional surgery and antibiotic treatment (Kočišová et al. 2003).

To treat the wounds by this method we can use only those fly larvae that can consume necrotic tissue and clean the wound in this way. This includes Phormia regina (Meigen, 1826), Protophormia terraenovae (Robineau-Desvoidy, 1830) and Lucilia sericata (Meigen, 1826) belonging to the family of blowflies. Blowflies (Calliphoridae) are conspicuously blue-green flies with metallic shine, some of them with gold colouring, with complete metamorphosis. After the fertilised flies lay eggs to the culturing substrate, larvae of the first stage, 1.5-2 mm long, develop (Byrd and Allen 2001). These larvae are applied to affected wounds. In the subsequent phases, these larvae grow to the second (approximately $8 \mathrm{~mm}$ ) and third $(15-17 \mathrm{~mm})$ stage. The mature, third-stage larva stops to consume food and begins to prepare for becoming a pupa inside the shed skin. The larvae of this phase are no more used for any treatment and are removed from the wounds. Larvae of most blowflies are necrophagous, i.e. they develop mostly in the bodies of dead vertebrates where, by secretion of digestive fluids, decompose the necrotic tissues and in this way accelerate the disintegration of dead tissues. Larvae of other than above mentioned species of the family Calliphoridae (blowflies) as well as larvae of species of the family Sarcophagidae (flesh-flies) are not useful for this treatment as they consume both necrotis and live tissues and can cause myiases (Knotek et al. 2005).

\section{Materials and Methods}

Adult flies were kept in special cages in an insectary at $24-26^{\circ} \mathrm{C}$, relative humidity of $50-60 \%$, with 12 -h daylight regimen. They were fed glucose and animal protein extract ad libitum and had a constant access to water. Containers with the nutrient medium, prepared according to the basic method by Sherman and Tran (1995), were placed to the cages for capturing the eggs. Bacterial flora on the surface of eggs, larvae and adult flies depends qualitatively and quantitatively on the environment in which they are held. The total plate counts on eggs ranged between 2 and $24 \times 10^{2}$, those on larvae between $2 \times 10^{3}$ and $2 \times 10^{5}$ and the number of microorganisms recovered from the surface of adult flies ranged between $1 \times 10^{2}$ and $6 \times 10^{6}$. To reduce the bacterial contamination of eggs and larvae we used substances with disinfectant properties, namely per acetic acid and antibiotic streptomycin.

The sheep were treated with larvae of Lucilia sericata (Meigen, 1826). The larvae were applied to wounds (Thomas et al. 2002) in the quantity of 8-12 larvae per $1 \mathrm{~cm}^{2}$ of wound surface according to the amount of the produced necrotic tissue. After application of larvae, the wounds were covered with a sterile perforated cellophane foil with a tamponade and dressed with a sterile bandage. 
The treatment was carried out on 6 sheep of Valachian breed that were separated from the basic herd during the treatment. The treated sheep were kept and fed under appropriate housing and care conditions complying with the respective directives of the government of SR determining the requirements on protection of animals used for experimental and other scientific purposes (Korim et al. 2003). We treated a total of 7 hoofs, of that 4 pelvic and 3 thoracic. In three cases we diagnosed acute inflammation of interdigital skin and in remaining four purulent inflammation of the pododerm. The treatment was carried out with larvae of Lucilia sericata in the Ist developmental stage which were treated prior to application with $1 \%$ per acetic acid solution to devitalise the larval surface bacteria (Kočišová et al. 2001). The following procedure was used to treat the necrotic inflammation of the pododerm and interdigital skin in sheep:

1. Removal of purulent and necrotic keratin (Plate XI, Fig. 1)

2. Application of larvae of $L$. sericata of the $\mathrm{I}^{\text {st }}$ developmental stage in the amount of 8-12 larvae per $1 \mathrm{~cm}^{2} \mathrm{of}$ the inflamed area (Plate XI, Fig. 2).

3. Covering the larvae with a perforated sterile polyethylene foil.

4. Application of bandage (Plate XI, Fig. 3).

5. Inspection and redressing of the wound after removal of larvae of L. sericata of the III ${ }^{\text {rd }}$ stage by washing them out with a sterile saline solution (Plate XII, Fig. 4) on day 4 after their application. In case of need fresh larvae were applied again with the inspection on day 4, washing out of larvae and redressing the wound up to the healing (Plate XII, Fig. 5).

\section{Results and Discussion}

With the sheep hoofs the healing was checked on day 4 after application of larvae. Four sheep exhibited a marked improvement and initiation of healing already after the first application (Table 1), two sheep required additional treatment during which 100-120 new larvae were applied beneath the keratin hoof capsule.

Table 1. The course of treatment of dermatitis interdigitalis acuta (DIA) and pododermatitis purulenta (PP) with larvae of Lucilia sericata in sheep

\begin{tabular}{|c|c|c|l|l|}
\hline Sheep No. & $\begin{array}{c}\text { Diagnosis - } \\
\text { treated extremity }\end{array}$ & $\begin{array}{c}\text { Mean number } \\
\text { of applied larvae } \\
\text { in the It } \text { stage }\end{array}$ & $\begin{array}{c}\text { Redressing - day } \\
4 \text { after } \\
\text { application }\end{array}$ & \multicolumn{1}{|c|}{$\begin{array}{c}\text { Need for } \\
\text { additional } \\
\text { treatment }\end{array}$} \\
\hline 1 & DIA - RT & 80 & healed & - \\
\hline 2 & DIA - RT & 80 & healed & - \\
\hline 3 & DIA - LP & 100 & healed & - \\
\hline 4 & PP - LT & 160 & healed & - \\
\hline 5 & PP - LT & 160 & $\begin{array}{l}\text { inflammation } \\
\text { persisted }\end{array}$ & $\begin{array}{l}+; 100 \text { larvae, } \\
\text { healed by day } 8\end{array}$ \\
\cline { 2 - 5 } & PP - RP & 140 & $\begin{array}{l}\text { inflammation } \\
\text { persisted }\end{array}$ & $\begin{array}{l}+; 100 \text { larvae, } \\
\text { healed by day } 8\end{array}$ \\
\hline 6 & PP - RP & 200 & $\begin{array}{l}\text { inflammation } \\
\text { persisted }\end{array}$ & $\begin{array}{l}\text { 2 additional } \\
\text { treatments, after } \\
\text { application of } \\
120 \text { larvae, healing } \\
\text { by day 12 }\end{array}$ \\
\hline
\end{tabular}

RT - right thoracic limb; LT - left thoracic limb; RP - right pelvic limb; LP - left pelvic limb

After additional 4 days, the larvae were washed out and the sheep could return to the herd showing no symptoms of inflammation.

Scientific studies showed that by day 7 after application the larvae were able to remove most of the necrotic tissue (Mumcuoglu 2001). It has been assumed that the process of wound healing is associated with ingestion of necrotic tissue by larvae as they are able to liquefy this tissue enzymatically through secretion of proteolytic enzymes. At the same time, bacteria are washed out mechanically by serous exudate that is produced due to irritative effect of larvae inside the wound. Moreover, salivary glands of larvae release secretions with 
antibacterial effects (Bexfield et al. 2004). These secretions also contain ammonia, allantoin, urea and calcium carbonate that change the acidic environment of the wound to a beneficial alkaline one. The constantly moving larvae massage the healthy tissue, stimulate it mechanically and support production of new granular tissue. Humans treated by larval therapy showed positive responses as soon as after one or two redressings and approximately 100-600 larvae had to be applied depending on the size of wounds. Only in very serious cases the healing lasted several months.

Contamination of the wound with pathogenic microorganisms as a result of non-sterile larvae could lead to the most serious problem (Nuesch et al. 2002) encountered with the treatment by larvae. In addition to that there is a theoretical possibility of development of allergic reaction in the patient as a result of body-foreign larval proteins, however, no such case has been published as yet. If suitable species of larvae is used they do not burrow under the skin or in the surrounding healthy tissue nor remain in the wound to multiply.

The optimum combination of larval therapy and modern treatment methods can ensure successful healing of chronic wounds. In veterinary medicine larvae are prospective for the treatment of difficult-to-heal abscesses, chronic wounds of cutis and subcutis, even certain types of malignant and benign tumours as a replacement of surgical interventions or in combination with them. Larval therapy can also help to limit the use of antibiotics in animals and in this way to eliminate the negative consequences of their use.

\section{Použitie larvoterapie na ošetrenie zápalov medziprstovej kože u oviec}

Larvy nekrofágnych múch Lucilia sericata Meigen (Diptera: Calliphoridae) boli použité v rámci alternatívneho spôsobu liečby oviec s hnisavým zápalom škáry. Ovce boli ustajnené na školskom polnohospodárskom podniku v Zemplínskej Teplici. Pred aplikáciou lariev boli paznechty neúspešne ošetrené v $10 \%$ kúpeli síranu mednatého a priamou aplikáciou alkoholového roztoku oxytetracyklínu do medziprstového priestoru. Šest̉ negravidných oviec vo veku 2-4 rokov s hmotnostou od 43 do 57 kg bolo ošetrených larvami I. vývinového štádia Lucilia sericata (Diptera: Calliphoridae). Larvy boli aplikované priamo do ošetrovaných rán, v množstve 8-12 kusov na $1 \mathrm{~cm}^{2}$ rany, avšak predtým boli odstránené poškodené časti tkaniva a rohoviny. Účinok jednorázovej aplikácie bol badatelný už po 3-6 dňoch. Čistenie rán bolo selektívne a rýchle. Celkové ošetrenie zvieratá dobre znášali. Nové vrstvy granulačného tkaniva sa vytvorili nad celými ošetrovanými plochami. Potvrdilo sa, že larvy L. sericata sú schopné vyčistit rany už po jednorázovej aplikácii.

\section{Acknowledgements}

The study was conducted within the Project VEGA No. 1/9016/02 and the basic research of National Reference Laboratory for Pesticides at the University of Veterinary Medicine in Košice. The authors wish to express thanks to Dr. Carita Hanson from the Dermatological Clinic in Göteborg who kindly supplied larvae of Lucilia sericata for breeding in our institution.

\section{References}

BEXFIELD A, NIGAM Y, THOMAS S, RATCLIFFE NA 2004: Detection and partial characterisation of two antibacterial factors from the excretions/secretions of the medicinal maggot Lucilia sericata and their activity against methicillin-resistant Staphylococcus aureus (MRSA). Microbes and Infection 6: 1297-1304

BOUNDRY T 1983: Foot problems in sheep. The veterinary clinics of North America: Large animal practice 5: 482-484

BYRD JH, ALLEN JC 2001: The development of the black blow fly, Phormia regina (Meigen). Forensic Science International 120: 79-88

DICKE RJ 1953: Maggot therapy of actinomycosis. J Econ Entomol 46: 706-707

DISSEMOND J, KOPPERMANN M, ESSER S, SCHULTEWOLTER T, GOOS M, WAGNER SN 2002: Treatment of methicilin-resistant Staphylococcus aureus (MRSA) as part of biosurgical management of a chronic leg ulcer. Hautarzt 53: 608-612

GRIFFIN D 1998: Feedlot diseases. The Veterinary Clinics of North America: Food Animal Practice, 14: $213-215$ 
HINSHAW J 2000: Larval therapy: a review of clinical human and veterinary studies. World wide wounds 4: 1-7

KOČIŠOVÁ A, PISTL J, TOPORČÁK J, ČONKOVÁ E, MOLČÁNYI T, CIBUR P 2001: Bacterial microflora on larvae of Phormia regina flies used in an alternative treatment of chronic wounds of humans and animals. In: Proc. " $22^{\text {nd }}$ Congress of Czechoslovak Microbiological Society - HEALTH AND MICROORGANISMS", Košice, 205 p. (In Slovak).

KOČIŠOVÁ A, ČONKOVÁ E, PISTL J, TOPORČÁK J 2003: First non-conventional veterinary treatment of skin infections with blowfly larvae (Calliphoridae) in Slovakia. Bull Vet Inst Puławy 47: 487-490.

KORIM P, BUGARSKÝ A, JURIŠ P, HADBAVNÝ M, KORIMOVÁ J 2003: Protection of experimental animals. Slov Vet Čas 28: 10-12 (In Slovak)

KNOTEK Z, FISCHER OA, JEKL V, KNOTKOVÁ Z 2005: Fatal myiasis caused by Calliphora vicina in Hermann's tortoise (Testudo hermanni). Acta Vet Brno 74:123-128

MUMCUOGLU KY 2001: Clinical applications for maggots in wound care. Am J Clin Dermatol 2: 219-227

NUESCH R, RAHM G, RUDIN W, STEFFEN I, FREI R, RUFTI T, ZIMMERLI W 2002: Clustering of bloodstream infections during maggot debridement therapy using contaminated larvae of Protophormia terraenovae. Infection 30: 306-309

SHERMAN RA, TRAN MJ 1995: A simple sterile food source for rearing the larvae of Lucilia sericata (Diptera: Calliphoridae). Med Vet Entomol 9: 393-398

WHITTIER WD, UMBERGER SH 1997: Control, treatment, and elimination of foot rot from sfeep. Virginia Cooperative Extension, Sheep, Publication 410-028: 1-4

SHERMAN RA, PECHTER EA 1988: Maggot therapy: a review of the therapeutic application of larvae in human medicine, especially for treating osteomyelitis. Med Vet Entomol 2: 225-230

THOMAS, S, WYNN, K, FOWLER, T, JONES, M 2002: The effect of containment on the properties of sterile maggots. Br J Nurs 11 (12 Suppl): 21-26

VISTNES LM, LEE R, KSANDDER GA 1981: Proteolytic activity of blowfly larvae secretions in experimental burns. Surgery 90: $835-841$ 
Plate XI

Kočišová A. et al.: Maggot Debridement... pp. 277-281
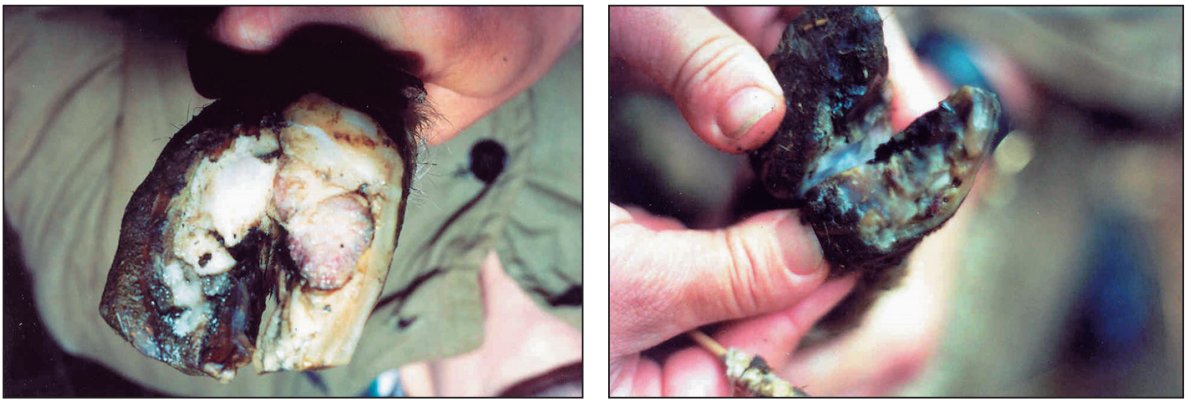

Fig. 1. Removal of purulent and necrotic keratin
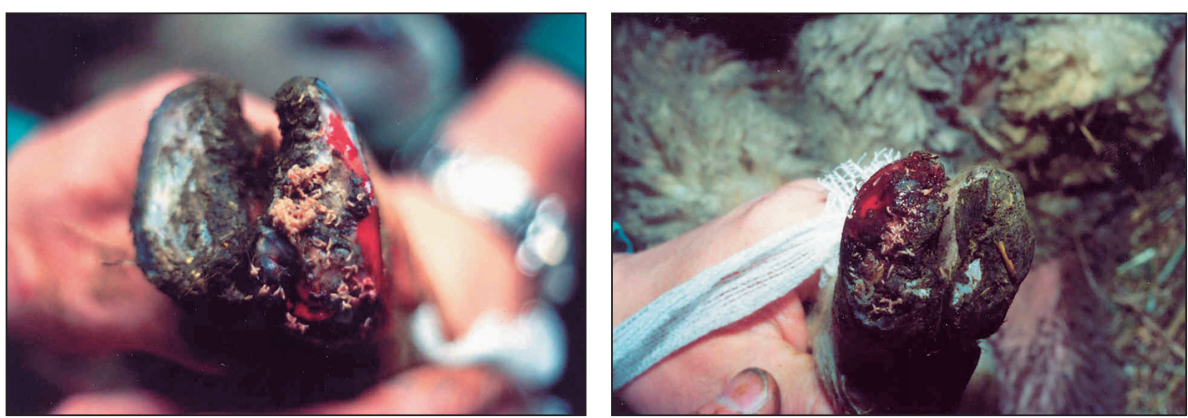

Fig. 2. Application of the Ist stage larvae of $L$. sericata
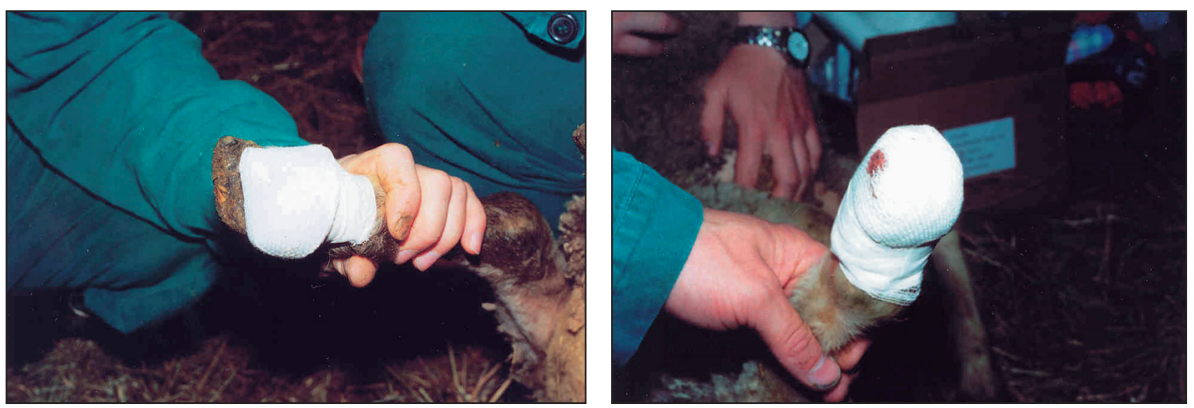

Fig. 3. Dressing of the wound 


\section{Plate XII}
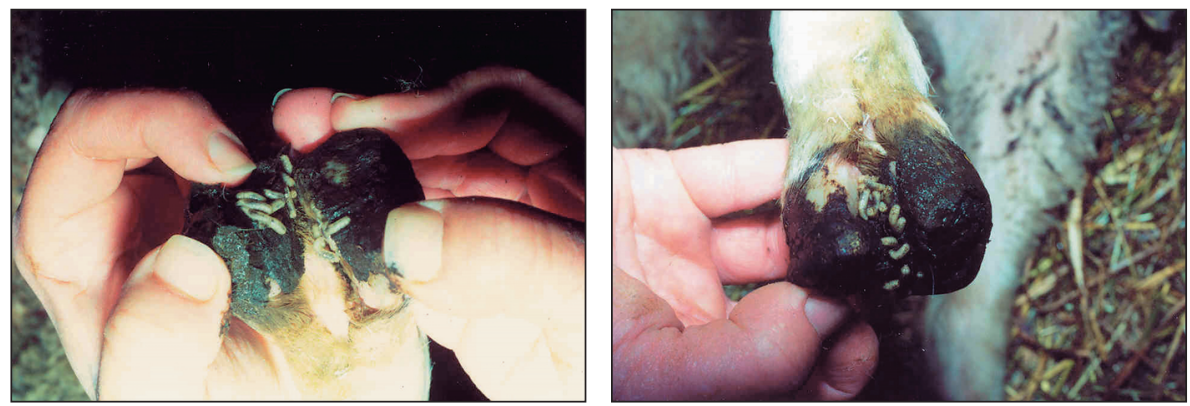

Fig. 4. Washing out the IIIrd stage larvae of $L$. sericata by a sterile saline solution
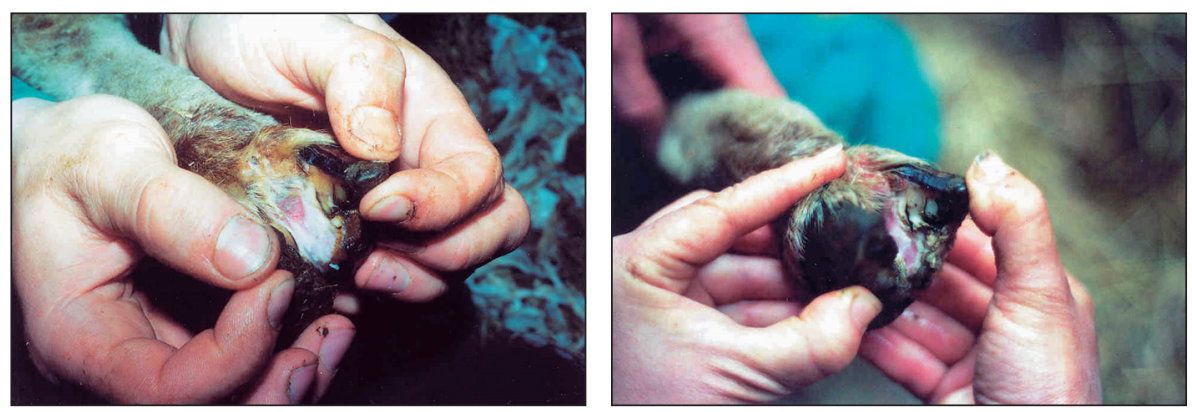

Fig. 5. Healing of the wound and production of new granular tissue 